\title{
Opening the Black Box of Remote College Counseling using Text-as-Data
}

Lily Fesler

June 2020

\begin{abstract}
Many programs remotely disseminate information to students about the college application process, but there is little evidence as to how students engage with this information. This paper uses text-as-data methods to examine 400,000 text messages exchanged between remote college counselors and 15,000 low- and middle-income high school seniors. I show that students are seven to eight times more likely to have productive conversations with counselors about financial aid offers and financial aid applications than about college lists. These findings reveal the complexity that remote programs face in providing more personalized advice to students, as well as demonstrate how text-as-data methods can combine qualitative and quantitative analysis to generate useful information about how students substantively engage with large-scale educational programs.
\end{abstract}


Although most students aspire to attend college, many cannot successfully navigate the college application and enrollment process. This is particularly true for low income students. Prior studies have shown that intensive one-on-one college advising can provide a crucial support for students during this process and can increase the chances that students enroll and persist in college, but these programs are expensive to scale (Barr \& Castleman, 2017; Carrell \& Sacerdote, 2017). In response, programs have attempted to scale college advising by providing these counseling services remotely, by sending information to students via brochures, emails, and text messages. Despite some early and notable successes (Hoxby \& Turner, 2013), many recent scaled-up programs have had no impact on students' probability of enrolling in college (Bird et al., 2019; Gurantz et al., 2019). It has been challenging to fully evaluate why these programs may not be effectively influencing student enrollment without a deeper understanding of how students respond to counselor outreach.

This paper provides new insights into student receptivity to remote college counselors by examining 400,000 text messages exchanged between remote college counselors and high school students. I analyze a program in which remote college counselors initiated conversations via text message with 15,000 high school seniors who are low- or middle-income and academically ontrack for college. This is a group of students that is of particular interest in the college access literature, as they are academically prepared for college but less likely to enroll in a high-quality institution than their higher-income peers (Hoxby \& Avery, 2012). Given that 95 percent of teens have access to a smart phone, texting is an effective way to reach students of this age (Anderson $\&$ Jiang, 2018). This program is intended to complement any information that students receive from their high school counselors. 
Counselors initiated text-message conversations with students on topics such as constructing college lists, submitting financial aid applications, understanding financial aid offers, and completing any necessary summer steps before fall enrollment (like taking placement tests, submitting immunization forms, and signing up for new student orientation). Given the passive nature of text messaging, not all messages elicited responses from students equally. I evaluate which of these topics are most likely to generate a 1) response, 2) repeated response, and 3) productive engagement between students and counselors that allows students to progress in the college application process. Instead of taking for granted that the information that counselors disseminate to students is received in the intended way, this analysis uses text-as-data and machine learning techniques to measure the topics that students and counselors productively discuss in real time as students navigate the college application process.

This paper has two primary contributions. First, this paper provides guidance to the designers of remote counseling programs as to the types of messages that are the most likely to generate productive engagement. I find that students are seven to eight times more likely to productively engage with remote counselors about their financial aid offers (15 percent of students) and their financial aid applications (13 percent of students) rather than their college lists ( 2 percent of students). Remote counselors productively engaged with students by reminding them about pertinent financial aid deadlines that they had not yet met, helping them troubleshoot FAFSA issues, and explaining screenshots of financial aid offers to them. These patterns also reveal the complexity of influencing something as subjective and personal as a student's college list via a remote texting program. Very few students stated that they were interested in adding the remote counselors' suggested schools to their list, despite the fact that influencing students' college lists was one of the primary aims of the program. 
Second, this paper demonstrates how text-as-data methods can expand our understanding of how students engage with an intervention. Prior studies have primarily relied on measuring the number of times counselors make contact with students to measure engagement (Castleman \& Page, 2016; Nurshatayeva et al., 2020; Page et al., 2020; Page \& Gehlbach, 2017; Phillips \& Reber, 2019a). However, this type of engagement measure provides limited information about whether students substantively engaged with the intervention materials. In this study, I show that there is little relationship between students' probability of responding to a counselor message on a given topic and their probability of productively engaging with the counselor on that same topic. This discrepancy is both due to 1) students being responsive to the messages but either not needing assistance or not being receptive to counselor input (e.g. texting back-and-forth with counselors about their college lists but rejecting any schools that counselors suggest that they add to their college list), and 2) students and counselors switching topics from the set topic for that month to discuss whatever is most pressing for the student at that time (e.g. a counselor question about their college decision quickly turns to a much longer discussion of their financial aid offer). Some studies have instead utilized qualitative methods to better understand engagement with a text messaging program (Weixler et al., 2019), but these methods are time consuming to scale. This paper demonstrates how researchers can combine careful qualitative coding with supervised machine learning to better measure engagement at scale.

\section{College Application Process}

\section{Application Steps}

Even though many students aspire to attend college, many students do not successfully complete any college applications (Klasik, 2012). Considering the length and complexity of the 
college application process to a four-year institution, this is not surprising. Students need to construct a list of schools they would be interested in attending, take any required entrance exams (like the SAT or ACT), fill out applications for each of those schools, make sure their transcripts and entrance exam scores are sent to their colleges of interest, fill out the Free Application for Federal Student Aid (FAFSA) and any state-specific financial aid forms, respond to any requests for financial aid verification, read and understand any financial aid offers they receive, make a decision about which college to attend considering their financial aid packages and personal preferences, and then complete any necessary summer steps for the college (like taking placement tests, submitting immunization forms, and signing up for new student orientation).

Students struggle with each part of this process. Studies show that students have trouble with finishing their applications (Avery \& Kane, 2004), submitting their FAFSAs (Bettinger et al., 2012), responding to financial aid verification requests (Cochrane et al., 2010), understanding their financial aid offers (Burd et al., 2018; Marx \& Turner, 2018), and completing any necessary summer steps before enrolling (Castleman \& Page, 2014).

This process is even less navigable for low-income students. Low-income, highachieving students who aspire to attend college are less likely to apply to academically matched schools than their high-income, high-achieving counterparts (Hoxby \& Avery, 2012). Lowincome students' college attendance is also more reliant on their successful FAFSA submission, and they may also need to complete additional financial aid verification steps that can impact their eligibility for the Pell Grant (Evans et al., 2017).

Several theories illuminate why many students may struggle with the college application process. Students may not sufficiently optimize for long-term outcomes, and low-income 
students may have more competing pressures during their senior year than high-income students (including work and family responsibilities) (Thaler \& Sunstein, 2008). They thus may be more focused on their short-term obligations over their longer-term investment in their future (Castleman \& Page, 2015). Low-income students may also lack the type of social capital necessary to be aware of all of the components of the college application process and the longterm benefits of a college education (Bourdieu, 1986; Dika \& Singh, 2002; Perna, 2006).

\section{College Counseling and Support}

College counselors can serve as a crucial support for students during this complicated process. Prior research has shown that access to college counselors increases the chances that students apply to and enroll in college (Castleman \& Goodman, 2018; Hurwitz \& Howell, 2013). However, many students do not have the access to college counselors that they need. The average public-school counselor is responsible for 482 students, which is twice the recommended counselor-to-student ratio of 250 to 1 (Avery et al., 2014; Clinedinst \& Koranteng, 2017). Low-income students also have less access to college counselors than higher-income students. In a study conducted in Boston public schools, only 17 percent of students who attended a lower-income school met with a guidance counselor at least four times, as compared to the 55 percent of students in a higher-income school (Avery \& Kane, 2004). Only 28 percent of public schools have a full-time college counselor, as compared to 49 percent of private schools (Clinedinst \& Koranteng, 2017). Many low-income students instead are forced to conduct research on their own (sometimes only including schools who have sent them mail or who they have seen on television), or with help from their parents (who may have little knowledge of the college application process) (Roderick et al., 2008). 
Ideally, low-income students would have access to additional in-person college counselors, but many public high schools are resource constrained and are unable to hire additional counselors (Perna et al., 2008). In this context, many programs have emerged to provide students with information about the college application process to supplement their high school's college counseling program, with mixed effects. Programs that give students access to additional in-person counselors have generally found positive impacts (Barr \& Castleman, 2017; Carrell \& Sacerdote, 2017), but remote counseling programs have shown more mixed effects (Gurantz et al., 2019; Phillips \& Reber, 2019a). Remote programs that allow for two-way communication between counselors and students may have more positive impacts than programs that only send information one-way to students (Bird et al., 2019), and have had more success in helping students to submit their financial aid forms and complete any necessary prematriculation steps than in influencing where students enroll (Page et al., 2020; Page \& Gehlbach, 2017; Phillips \& Reber, 2019a). In addition, students are more interested in programs that emphasize college affordability over college choice (Hyman, 2019).

None of these programs have gathered and analyzed detailed data on how students react to counselor assistance. Some programs collected information on whether students have accessed a college information website (Gurantz et al., 2019; Hyman, 2019) or the number of times counselors successfully made contact or texted back-and-forth with a student (Castleman \& Page, 2016; Nurshatayeva et al., 2020; Page et al., 2020; Page \& Gehlbach, 2017; Phillips \& Reber, 2019a). One program reported counselors' notes on the topics that they discussed with students, but not on how students received the information (Barr \& Castleman, 2017). Without more detailed information about how students respond to counselor advice, it is challenging to understand how to improve upon these programs. 
At the same time, more programs in recent years have been able to reach more students via two-way texting, either through real remote counselors texting students or via chatbots texting students (Bird et al., 2019; Page \& Gehlbach, 2017). Text-as-data methods allow researchers to analyze virtually unlimited numbers of these messages without having to manually read and code each message and are beginning to be used more within educational contexts (Author, 2019).

In this paper, I apply novel text-as-data methods to understand when a counselor-initiated interaction leads to a productive engagement between the counselor and student. This contributes to the literature on college counseling programs and is the first study to analyze how students respond to and interact with college counselors at scale. This paper intends to demonstrate the ways in which remote counselors can productively support students in the college application process, as well as demonstrate how text-as-data methods can measure program engagement across a variety of contexts.

\section{Remote Counseling Program}

Four remote college counselors from a non-profit college advising organization (on behalf of the College Board) sent text messages to 15,000 low- and middle-income high school seniors who were on-track for college in 2016-17. Text messaging is a particularly effective way of reaching high school students, given that 95 percent of teens have access to a smart phone, 98 percent of cell phone owners can access text messages, and text messages have a 95 percent open rate (Anderson \& Jiang, 2018; Ehrlich, 2013). Counselors sent ten broadcasts (approximately once per month) to students to initiate conversations about college lists, financial aid applications, the financial aid verification process, the college decision, financial aid offers, and 
summer steps. Students were divided into twelve batches, so that about 1,250 students received messages each school day. Real counselors responded to all students who replied to each broadcast, regardless of whether the student wanted to talk about the broadcasted topic or another relevant topic. Counselors were assigned to the same students throughout the program, so that each student would only ever interact with one of the four counselors. This also allowed counselors to follow-up on students' individual circumstances that they had shared in previous communications.

\section{Sample}

To be included in the program, students indicated on the SAT that they were willing to be contacted by the College Board via text message. All students were on-track for college (i.e. were between the $50^{\text {th }}$ and $90^{\text {th }}$ percentiles in the national SAT distribution), lived in one of eight states (CA, FL, MA, MI, NC, NY, PA, and TX), and were identified as low- or middle-income. PSAT and SAT questionnaire data either do not ask for income levels or may be subject to nonresponse, thus limiting the ability to accurately identify students who are likely to enter college with financial need. To handle this, we relied on two approaches. First, we considered students to be low-income if they received a College Board SAT fee waiver. Eligibility for fee waiver status could occur through a variety of methods, most commonly National Student Lunch Program eligibility, receipt of public assistance, or participation in an authorized program serving lowincome students (e.g., Upward Bound). As these qualifications rely on students sharing this potentially sensitive information with their school counselors, not all low-income students who would qualify for a fee waiver are identified. The College Board supplements fee waiver information by developing a methodology to identify low- and middle-income students through 
an algorithm that includes student self-reported data on the SAT's student data questionnaire (SDQ), high school attended, and census tract. Low-income students were identified then by either receipt of an SAT fee waiver or an estimated annual income below approximately $\$ 58,000$; moderate-income students were identified based on incomes below approximately $\$ 77,000$ per year, but above the low-income threshold.

Table 1 shows the characteristics of students in the sample, by whether they responded to at least one counselor broadcast throughout the program. 43 percent of respondents identified as Latinx, 27 percent as White, 14 percent as Asian, 10 percent as Black, 5 percent as multiple races, and 56 percent as female. 27 percent of respondents were first generation and 58 percent are low-income (i.e. have an estimated family income below $\$ 58,000$ ). The remaining 42 percent of respondents are middle-income (i.e. have an estimated family income between $\$ 58,000$ and $\$ 77,000)$. On average, respondents have a GPA of 3.6 , SAT scores of 570-580, and primarily attend high school in a city or the suburbs. Nonrespondents are similar to respondents across many of the characteristics, but are slightly less likely to identify as female, have slightly lower GPAs and SAT reading scores, and are more likely to attend high school in a rural area rather than a city. Over the course of the program, 600 students (4 percent) opted out of receiving messages.

Insert Table 1 here.

\section{Program Objectives}

The counselors were trained to aim for two primary objectives. First, they encouraged students to apply to at least six colleges, and balance their applications across a range of reach, match, and safety schools. (Schools are a "reach" if the student's SAT score is below the 
school's $25^{\text {th }}$ percentile or less than 20 percent of applicants are admitted to the college, a "match" if the student's SAT score is between the $25^{\text {th }}$ and $75^{\text {th }}$ percentiles of the school's SAT scores, and a "safety" if the student's SAT score is greater than the $75^{\text {th }}$ percentile of the school's SAT scores.) Second, they aimed to increase the number of students who enrolled in college, by helping students complete their college applications, financial aid applications, and any necessary summer steps before enrolling.

Counselors received specific training about how to steer students towards completing applications to a range of affordable colleges. For example, counselors would encourage students to apply to additional schools if students stated that they only had one or two schools on their college list. Counselors would also ask students additional questions about other parts of the process if they had already completed a given step. If, for instance, students had already had a well-rounded college list, counselors might also inquire about the status of students' applications. In addition, counselors were trained on how to respond to specific questions about FAFSA, how to read and interpret financial aid offers, and the most common steps students had to complete between accepting the admission offer and enrolling in the fall. Counselors would also follow-up on comments made students made during previous interactions if they were not fully resolved. For example, counselors might ask students if they had successfully connected with their college's financial aid office if the counselor and student had previously discovered issues with the student's financial aid offer in the previous interaction.

\section{Counselor Broadcasts}

Each counselor broadcast was intended to start a conversation about a particular range of topics, including college lists (broadcast 1), financial aid applications (broadcasts 2-4), financial 
aid offers and bills (broadcasts 5, 8, and 9), the college decision (broadcast 6), and summer steps (broadcast 7). Table 2 shows the language included in each broadcast.

Insert Table 2 here.

The first broadcast asked students if they knew where they wanted to apply to college and was sent between October and December. In this exchange, counselors' primary objective was to determine whether students had a balanced college list that included at least six schools, and if not, to encourage students to apply to additional schools. In particular, counselors suggested that students apply to schools that tended to be affordable and that students from their high school and SAT score range had been successful at in the past (i.e. higher graduation rates). Prior research has shown that emphasizing college affordability over college choice generates more interest from students (Hyman, 2019). If students were not interested in counselors' college suggestions, counselors would ask additional questions about their college preferences so that they could suggest additional schools that might be of interest to the student. For schools in which students expressed interest, counselors also reminded students of the application deadlines, inquired if students had questions about their college applications, and helped students understand how to use any fee waivers.

The second, third, and fourth broadcasts initiated conversations about the FAFSA, Texas Application for State Financial Aid (TASFA, for students who live in Texas and are not eligible for FAFSA), or the Dream Act application (for students who live in California and are not eligible for FAFSA), and were sent between December and March. The second broadcast asked students if they had submitted their FAFSA, TASFA, or Dream Act application yet. Counselors commonly provided information to students about how to create a Federal Student Aid (FSA) ID to start the FAFSA and responded to specific questions students had about their FAFSA 
application (e.g. not knowing what number to fill in for a question or having technical difficulties on the site). They also encouraged students to apply for additional scholarships. The third broadcast followed up on the FAFSA, TASFA, or Dream Act application. If students told counselors they completed their FAFSA in the previous interaction, the broadcast asked students if they had received financial aid verification steps. Otherwise, the broadcast again inquired if students had completed their FAFSA yet and encouraged them to complete it as soon as possible. If students told counselors they completed their FAFSA in either the second or third broadcast, the fourth broadcast asked students if they had checked their Student Aid Report (SAR) in their FAFSA to verify that all of their colleges were listed. Otherwise, the broadcast again reminded students to submit their FAFSA, TASFA, or Dream Act application.

The fifth broadcast asked students if they had received financial aid offers from the colleges to which they were accepted and was sent in March and April. In this interaction, counselors were trained to help students find their financial aid offers in their online portals, help them call the admissions office if they are missing an offer, help them understand their offers, and help them consider the affordability of the college. Counselors also offered to explain all of the amounts on students' financial aid offers and estimate their total cost of attending the college if students sent in screenshots of their offers to counselors.

The sixth broadcast asked students if they had made a college decision and was sent in April and May. If not, counselors offered to serve as a resource to help students think through their decision.

The seventh broadcast asked students if they were aware of which steps they needed to take after accepting an admission offer in the spring and enrolling in the fall and was sent in May and June. Counselors encouraged students to sign up for new student orientation, submit any 
necessary immunization forms, and take any required placement tests. They would also point them to their institution-specific checklist online.

The eighth and ninth broadcasts asked students about their upcoming bill and were sent in June through August. The eighth broadcast asked if students had seen their bill yet. If not, counselors could help students find their bill online, or contact the institution to inquire about when they would be able to see it. Counselors would also help students understand the amounts on their bill given their financial aid offer, and help students consider if they wanted to sign up for a payment plan. The ninth broadcast asked students if they had paid their fall bill, and strongly encouraged them to do so before the deadline.

The tenth broadcast asked students if they had any additional questions before the texting program ended and was sent in September. The counselors did not have an intended agenda for this conversation.

\section{Dashboard}

As counselors interacted with a student, they could see information about the student on their dashboard. They could view the student's state and zip code, whether they were lowincome or middle-income, their PSAT and SAT score ranges (in 200 point increments), the number of Advanced Placement (AP) exams they had taken, the number of free college application fee waivers (CAFWs) they had received from the College Board, the number of free score sends they had received from the College Board, and the student's "starter list" of potential colleges. The starter lists contained twelve colleges that were chosen based on the schools with the highest graduation rates for students from their county with similar SAT scores. For each of the twelve colleges on students' starter lists, counselors could see the college name, state, and the 
$25^{\text {th }}$ and $75^{\text {th }}$ percentile SAT scores for students who attend the institution. This list of colleges allowed counselors to personalize college suggestions to the student in the first broadcast. The dashboards also allowed counselors to track their prior interactions with the student, so counselors could tailor each interaction based on their prior interactions with that student.

Data include every text message sent by a counselor or student during the study, as well as all information on counselors' dashboards. They also include students' background characteristics, including students' race, gender, predicted income, first-generation college status, SAT scores, high school GPA, and high school attended. I also connect these data to the Common Core of Data from the National Center for Education Statistics, which gives information on the urbanicity of students' high school.

\section{Methods}

I measure three types of student engagement in each student-counselor interaction: response, repeated response, and productive engagement. Response is measured as whether the student sent at least one message to the counselor after the broadcast. Repeated response is measured as whether the student sent a second message, beyond their initial 'yes' or 'no' text in response to the broadcast. Both measures are constructed by counting student messages, and do not require machine learning.

Productive engagement is measured as whether students learn new information about the college application process, are reminded to take a step they have not yet taken or agree to make a change to their college application (described in more detail in Step 2 below). I measure whether productive engagement about any part of the college application process occurred, as 
well as whether productive engagement occurred for each given part of the process (e.g. college lists or FAFSA).

To measure productive engagement, I use a text-as-data method that combines qualitative coding with supervised machine learning. This process comprises four steps. First, I chunk the text messaging data into distinct observations (which I call "interactions"). Second, I hand code a random subset of those interactions for whether any productive engagement between the counselor and student occurred and the part of the college application process in which it occurred. Third, I build a supervised machine learning model that learns the relationship between the content of the text messages and whether productive engagement occurred in each message. Fourth, I use the machine learning model to predict whether productive engagement occurred in the remaining text messages that I did not hand code. I describe each of these steps in more detail below.

\section{Step 1: Divide Text Data into Interactions}

I first divide the text messages into distinct interactions. A given interaction includes all text messages exchanged between counselors and students after one counselor broadcast and before the next broadcast, which will ensure that all relevant back-and-forth between counselors and students in each conversation are analyzed together. These interactions usually last for a couple of hours up to a couple of days. I have 18,032 interactions in total (and 387,000 individual text messages).

\section{Step 2: Hand Code Subset of Interactions}


I conduct a content analysis to determine the instances in which students and counselors could productively engage. I used an inductive coding process, in which two coders read through a subset of interactions to identify the most common ways that productive engagement could occur and the different parts of the college application process in which productive engagement could occur. The coders identified that productive engagement occurred when 1) students learned new information about the college application process, 2) students were reminded to take a step they had not yet taken, or 3) students agreed to make a change to their college application (each of which are described in further detail below). The coders also identified five primary parts of the college application process in which productive engagement could occur. These included: 1) college list, 2) college application, 3) financial aid application (primarily FAFSA), 4) financial aid offer, and 5) summer steps. (The coders also originally created a code for college decision but subsequently dropped it due to the infrequency with which it occurred in the data.) This process generated six binary productive engagement codes, for each of the five parts of the college application process plus a category for any productive engagement (regardless of topic). These five parts of the process are also aligned with prior literature on the college application process. (See Appendix A for the codebook.)

Productive engagement is coded as occurring if at least one of three conditions was present. First, interactions are coded as including productive engagement if students learn new information. Examples of this include when students ask a question (e.g. "where can I find my financial aid offer?") that counselors answer, students state something that is incorrect that counselors respond to with correct information (e.g. "I don't think that I'll take out the Pell grant because my family doesn't want loans"), or students send a screenshot of a financial aid offer that counselors help them interpret. Those three sample interactions would all be coded as 
including any productive engagement, as well as productive engagement about financial aid offers. If counselors ask students a question that they already know the answer to, that does not count as productive engagement (e.g. if a student responds "yes" to "Have you found your financial aid offer?").

Students are also coded as productively engaging if they are reminded to take a step they have not yet taken. For example, if counselors encourage a student to submit their FAFSA after they state that they have not yet done so, that is coded as productive engagement about FAFSA. But if the student states that they have already submitted their FAFSA, no productive engagement about financial aid has occurred. Even if there are multiple messages back-and-forth (e.g. in which the counselor confirms that the student has submitted FAFSA, completed any verification steps, and checked their Student Aid Report for their FAFSA), if the student has already successfully completed each of those steps there is no productive engagement. Note that in instances in which students agree verbally to work on their FAFSA that week, I cannot measure whether students log into FAFSA that week or not. Instead, I am measuring whether students are receptive to the information (i.e. are responsive to the counselor) and whether the interaction has the potential to help students along with the process.

Students are also coded as productively engaging if they agree to make a change to their college application. This most typically occurs with college lists. If, for instance, the counselor suggests that the student apply to a particular school to balance their college list and the student agrees, that would count as productive engagement about college lists. However, if the student does not agree to add it to their college list (stating, for example, that the school would be too close to home for them), then that is coded as no productive engagement. Again, I do not measure whether students ultimately apply to different schools after an interaction. I am instead 
measuring whether students are open to counselor feedback within the interaction and consider adding additional schools to their list.

An interaction only needs to contain one instance of productive engagement to be coded as including productive engagement and can include multiple forms of productive engagement in the same interaction. For instance, if students state that they have already found their financial aid offer (no productive engagement), but then text a screenshot of their financial aid offer for help understanding their financial aid package (productive engagement), that entire interaction is counted as containing productive engagement (about financial aid offers). If in that same interaction, students also ask about how to sign up for their college's orientation, then that interaction will be coded as including productive engagement about summer steps in addition to including productive engagement about financial aid offers.

I randomly select a subset of the interactions for two researchers to code to measure interrater reliability. Cohen's kappa for the six codes are all above 0.83 and are statistically greater than 0.65 (see Appendix Table B1). For interactions in which the coders differed, the coders discussed their rationales for their chosen codes and came to a common agreement about which codes were more appropriate for that interaction. The coders also coded some messages separately, leading to a total of 551 hand-coded interactions. Appendix B provides more information about this process.

\section{Step 3: Build a Supervised Machine Learning Model}

The hand-coded messages serve as training data for supervised machine learning models, which learn the relationships between the text of the interactions and whether different forms of productive engagement took place (the six productive engagement codes). Supervised machine 
learning methods are particularly well suited to making accurate predictions (Mullainathan \& Spiess, 2017). I assess how well different models perform, then use the best-performing model to predict the codes of the 17,481 interactions that I have not hand coded. This allows me to measure whether productive engagement occurred for all 18,032 interactions.

The first step in building this model is to convert my text data into a quantitative dataset. I simplify my text data by using the "bag-of-words" method, in which I discard information about word order, punctuation, and capitalization. This method also does not differentiate between words texted by counselors versus words texted by students. To simplify the text further, I remove word suffixes (i.e. stem the terms) and drop terms that occur in fewer than 2 percent of interactions. I then convert this processed text into a document-term matrix, in which each interaction is a row and each column represents a (processed) term. Each cell represents the number of times a given term occurred in an interaction.

I apply seven different machine learning algorithms to learn the relationship between the content of the interactions (as measured in my document-term matrix) and whether productive engagement took place. More specifically, I use elastic net, ridge, LASSO, random forests, support vector machine (SVM), neural nets, and an ensemble of the six methods. I assess the performance of each of the methods to determine how well each would be able to predict productive engagement outside of my training sample. I split my hand-coded data into a training set and a test set. The training set is used to build the machine learning models for each of the six codes, and the test set is used to assess how accurately each of the models predict outcomes using data not included in the training of the model. This separation of training and test set is crucial to ensure that the machine learning models are not overfit to the data used to build the model. Appendix B provides a full description of the machine learning process. 
Table 3 shows the accuracy of each of the models for the six codes (see Appendix B for additional performance metrics in addition to accuracy). SVM outperforms the other methods for each of the six codes (with the exception of random forest, which outperforms SVM in predicting the FAFSA productive engagement code by 0.9 percentage points). For each of the codes, 94 to 99 percent of interactions were correctly coded by the model.

Insert Table 3 here.

\section{Step 4: Predict Productive Engagement for Remaining Interactions}

Because SVM works particularly well in predicting the six codes in my data, I use this method to predict whether the six types of productive engagement occurred in the remaining 17,481 non-coded interactions. This produces interaction-level outcome data. All interactions that generated no student response are also automatically coded as not including any productive engagement.

\section{Adjusting Proportions for Predictive Performance}

Despite the high accuracy of each of the six predictive models at the interaction level, I also check whether any small inaccuracies in predictive performance may impact my samplelevel estimates. Using the Hopkins-King method (2010), I produce approximately unbiased and statistically consistent proportions by directly adjusting for how well the model predicts true positives and true negatives. These adjustments are discussed in full in Appendix B and produce relatively similar proportions. My primary results tables show the unadjusted predictions, but I discuss the adjusted proportions in the results section as well. 


\section{Results}

\section{Response and Repeated Response}

Seventy one percent of the 14,860 students respond to at least one counselor broadcast, and 49 percent of students repeatedly respond to at least one broadcast (see the last row of Table 4). Students are the most likely to respond to broadcasts about the FAFSA application (36 percent of students), the college decision (30 percent of students), FAFSA verification (27 percent of students), and the college list (26 percent of students). Students are the most likely to repeatedly respond to counselors after the broadcast about the college decision ( 20 percent of students) and about the college list (13 percent). However, response rates by broadcast topic provide little information about the productivity of these interactions.

Insert Table 4 here.

\section{Productive Engagement}

Twenty-seven percent of the 14,860 students productively engage with the counselor on at least one topic (see the last row of Table 4). Students are most likely to productively engage after broadcasts about the FAFSA application ( 8 percent of students), the financial aid offer (7 percent of students), and the college decision ( 7 percent of students) (see the third column in Table 4). However, these percentages do not tell us about which topics students productively engaged. Students and counselors could both re-steer the conversation if the student needed more help with another part of the application process than the broadcasted topic. Thus, this table also breaks out productive engagement by the topic about which students and counselors productively engaged (columns 4-8 in Table 4). 
Throughout the program, 13 percent of students productively engaged about the FAFSA and 15 percent of students productively engaged about the financial aid offer (see the bottom row in Table 4). Much of the productive engagement about FAFSA occurred after the FAFSA broadcasts: six percent of students productively engaged about FAFSA after the FAFSA application broadcast, five percent after the FAFSA verification broadcast, and four percent after the FAFSA Student Aid Report broadcast (see Table 4 and Figure 1). The inductive coding process revealed that these productive conversations included counselors reminding students to fill out the FAFSA (for students who had not yet done so), as well as student questions about the Internal Revenue Service's data retrieval tool (which transfers federal tax return information onto the FAFSA), the FAFSA signature page (which requires signatures from the student and a parent), FAFSA webpage login issues, and how to send FAFSA to more than ten schools.

Insert Figure 1 here.

The productive engagement about the financial aid offer began after the financial aid offer broadcast ( 6 percent) and was sustained through the college decision broadcast ( 5 percent) as well as both broadcasts about the fall bill ( 2 to 4 percent) (see Table 4 and Figure 1). In fact, the college decision broadcast led almost entirely to discussions about the financial aid offer, as opposed to about the college decision. (The percent of interactions that included productive engagement about the college decision was so close to zero that I had to exclude it from the analysis.) These productive conversations included counselors prompting students to create an account on school websites (to be able to see their financial aid offer) and to call the school to find a missing financial aid offer, as well as student questions about different types of financial aid, how long their financial aid package lasts, how work study works, and whether taking out loans is advisable (among other questions). 
In contrast, only two percent of students ever productively engaged with counselors about their college lists (this increases to three percent with the Hopkins-King adjustment; see Appendix Table B3). Almost all these students productively engaged after the college list broadcast, and this lower level of productive engagement is also seen when comparing productive engagement at the broadcast level instead of across the entire program. For example, only 1.7 percent of students productively engaged after the college list broadcast, compared to 3.9 to 4.5 percent after the FAFSA broadcasts and 2.0 to 5.5 percent after the financial aid broadcasts. This indicates that the higher number of broadcasts about FAFSA and financial aid offers cannot fully explain the differences in productive engagement between college lists and financial aid. The productive engagements about college lists included students agreeing to consider counselors' suggested schools for them, as well as student questions about whether a college might be an academic fit for them and discussions about what is important to the student in a college.

A similar percent of students (1.7 percent) productively engaged about the college application, which also almost always happened after the college list broadcast. These conversations primarily centered around application deadlines, application fee waivers, and sending materials to colleges (like test scores, transcripts, essays, and letters of recommendation).

Four percent of students ever productively engaged about summer steps (this increases to six percent with the Hopkins-King adjustment; see Appendix Table B3). Almost all these engagements occurred directly after the summer steps broadcast, indicating that this was not a persistent issue for students. In addition, 1.5 percent of these conversations between counselors 
and students turned back to students' financial aid offers instead of the prompted summer steps conversation.

Interestingly, there is little relationship between whether students respond or repeatedly respond to counselors and whether they productively engage with counselors. More students respond and repeatedly respond to messages about college lists than about their financial aid offers and summer steps, yet more students productively engage about the latter two categories. Some of this is due to students' receptivity to answering counselor questions about what they have done so far (e.g. telling counselors what schools they are considering) but not necessarily being open to making a change to their applications or college lists (e.g. not agreeing to add any of counselors' college suggestions to their lists). Some of this is also due to students and counselors discussing different topics than the intended topic, generally due to students not needing or wanting help with the originally broadcast topic. For instance, some conversations around college lists morphed into conversations about submitting applications, and some conversations about summer steps shifted into conversations about financial aid offers.

\section{Heterogeneity by Student Characteristics}

In addition to estimating how frequently students respond, repeatedly respond, and productively engage overall, I also conduct an exploratory analysis in which I examine whether student engagement varies by ethnicity, family income, first-generation status and the urbanicity of the student's high school. Prior research has shown that counseling programs can have more positive impacts on Hispanic students and low-income students than other populations (Bettinger \& Evans, 2019; Cunha et al., 2018; Phillips \& Reber, 2019a). (I analyze students who identify as Latinx, which includes people from Central America, South America, the Caribbean, and 
Mexico; instead of students who identify as Hispanic, which includes people from Spanish speaking countries. These two terms overlap but are distinct (Salinas \& Lozano, 2019).) First generation students may also seek additional help, given that their families have less personal experience with the college application process. Students in more isolated schools (e.g. rural schools and towns) may also benefit more from additional information about colleges than students in less isolated schools (e.g. urban areas) (Dynarski et al., 2018; Hoxby \& Avery, 2012).

I find that students who identify as Latinx respond and productively engage at similar rates to students who do not identify as Latinx, but that the topics with which Latinx students productively engage with counselors differ from non-Latinx students (see Table 5). Latinx students are 0.7 percentage points (67 percent) less likely to productively engage with counselors about their college lists than non-Latinx students, but 0.7 percentage points ( 48 percent) more likely to productively engage about their college application than non-Latinx students and 0.7 percentage points (18 percent) more likely to productively engage about summer steps than nonLatinx students. This suggests that Latinx students in this study may have sought help with more concrete parts of the college application process (like submitting their high school transcripts and signing up for orientation) than more subjective parts of the process (like college lists), relative to non-Latinx students.

Insert Table 5 here.

First generation and low-income students are less likely than non-first generation and middle-income students to respond to counselors, but productively engage at similar rates to other students. This suggests that the first generation and low-income students who respond to counselors are more likely to have productive conversations than non-first generation and middle-income students who respond to counselors. Low-income students are also 0.8 
percentage points ( 25 percent) more likely to engage about summer steps than middle-income students, suggesting that low-income students may need more information about the prematriculation process. Low-income students are not more or less likely to productively engage about the financial aid application and financial aid offer than middle-income students, but this may be due to the fact that middle income students (whose family incomes are still less than $\$ 77,000)$ are also likely to need financial aid to afford college and thus still need to know how to navigate their financial aid applications and offers.

Students who attend high school in towns and rural areas are two percentage points more likely to respond and four percentage points more likely to repeatedly respond than students who attend high school in cities or suburbs. They are also two percentage points (15 percent) more likely to productively engage about their financial aid offers than urban and suburban students. This may reflect that students in these areas receive less support from their schools and counselors on how to navigate their financial aid offers, which often contain confusing jargon and can be difficult to understand (Burd et al., 2018).

Overall, despite differences by demographic group in the likelihood of ever responding to counselors' texts, there are no differences in who productively engages with counselors. This suggests that this program would not have had higher levels of overall productive engagement if it had been more targeted towards a specific demographic group. However, the low level of productive engagement about college lists may be partially driven by students who identify as Latinx, who are significantly less likely to productively engage about their college lists and also make up a large percentage of students in the study (42 percent).

Insert Table 5 here. 


\section{Discussion}

In this paper, I show that 15,000 low- and middle-income high school students were the most likely to productively engage with remote college counselors about financial aid offers and financial aid applications, rather than college lists. There are several potential reasons why we might see these patterns, despite this remote counseling program's emphasis on influencing students' college lists.

First, students may be more receptive to timely information than to personalized advice from remote counselors. The conversations around financial aid and summer steps tended to be more informational and procedural (e.g. how to submit FAFSA) whereas the conversations about college lists tended to be more personal (e.g. whether a particular college would be a good academic and financial fit for the student). It may be too challenging for remote counselors who do not know individual students well to meet the high bar of providing an appropriate personalized recommendation for each student. This is seen in students' responses to counselors, in which they would sometimes note that the counselor's college suggestion did not fit their location or major preferences, for example. If counselors had had more time to get to know students before giving them suggestions, perhaps they could have led to more productive discussions around college lists. For example, counselors in the V-SOURCE Complete virtual advising program provided several months for counselors and students to get to know one another before counselors began assisting students through the college application process, and counselors in this program did significantly increase students' probability of applying to a selective college (Phillips \& Reber, 2019a). However, programs that give counselors more time to get to know students often require many more counselors per student (which makes for a costlier program). For example, advisors in V-SOURCE were responsible for 26 students, 
compared to the advisor caseload of 3,750 students in this program and this higher caseload makes for a more expensive program (Phillips \& Reber, 2019b).

Second, the late October start time of this program may have been too late to influence students' college lists. One prior study showed that 80 percent of low-income students had not submitted any applications before October of their senior year (Avery \& Kane, 2004), but students could still be fairly set on their college list at this point. Other programs that were successful in changing students college lists reached out to students in the spring of their junior year or September of their senior year, when students may be more open to changing their college plans (Dynarski et al., 2018; Phillips \& Reber, 2019a). In contrast, the messages around FAFSA, financial aid offers, and summer steps may have been timelier for students given that all these steps occurred after the remote counseling program began. However, many application deadlines were still months away when counselors interacted with students, and many students voiced concerns about counselors' specific suggestions (as opposed to concerns about not having enough time to apply). This suggests that the timing of the program does not entirely explain the lower amount of productive engagement about college lists.

In addition to demonstrating the topics that generate productive engagement between high school students and remote college counselors, this paper also shows the importance of building more detailed engagement measures to improve our understanding of how students experience programs. Many prior studies have used simple response measures to determine student engagement with a program, but I show that there can be a negligible relationship between whether students respond or repeatedly respond to counselors and whether they productively engage with counselors. More students respond and repeatedly respond to messages about college lists than about financial aid offers and summer steps, yet more students 
productively engage about the latter two categories. To improve upon existing programs, we need to have better measures of which elements of the program are working well for students on the ground. For many two-way counseling programs, text-as-data methods can serve an important function in measuring the quality and productivity of interactions in addition to the quantity of interactions. 


\section{References}

Anderson, M., \& Jiang, J. (2018, May 31). Teens, Social Media \& Technology 2018. Pew Research Center.

Author. (2019). .

Avery, C., Howell, J. S., \& Page, L. C. (2014). A review of the role of college counseling, coaching, and mentoring on students' postsecondary outcomes. College Board, October, 115.

Avery, C., \& Kane, T. J. (2004). Student Perceptions of College Opportunities: The Boston COACH Program. In C. Hoxby (Ed.), College Choices: The Economics of Where to Go, When to Go, and How to Pay For It: Vol. ISBN. University of Chicago Press.

Barr, A., \& Castleman, B. (2017). The Bottom Line on College Counseling.

Bettinger, E., \& Evans, B. J. (2019). College Guidance for All: A Randomized Experiment in Pre-College Advising. Journal of Policy Analysis and Management, 0(0), 1-25.

Bettinger, E., Long, B. T., Oreopoulos, P., \& Sanbonmatsu, L. (2012). The Role of Application Assistance and Information in College Decisions: Results from the H\&R Block FAFSA Experiment. Quarterly Journal of Economics, 1205-1242.

Bird, K. A., Castleman, B. L., Denning, J. T., Goodman, J., Lamberton, C., \& Rosinger, K. O. (2019). Nudging at Scale: Experimental Evidence from FAFSA Completion Campaigns. In NBER Working Paper Series. http://www.nber.org/papers/w26158

Bourdieu, P. (1986). The forms of capital. In J. G. Richardson (Ed.), Handbook of Theory and Research for the Sociology of Education. Greenwood Press.

Burd, S., Fishman, R., Keane, L., \& Habbert, J. (2018). Decoding the Cost of College: The Case for Transparent Financial Aid Award Letters (Issue June).

Carrell, S., \& Sacerdote, B. (2017). Why do college-going interventions work? American Economic Journal: Applied Economics, 9(3), 124-151. https://doi.org/10.1257/app.20150530

Castleman, B. L., \& Goodman, J. S. (2018). Intensive College Counseling and the Enrollment and Persistence of Low-Income Students. Education Finance and Policy, 13(1), 19-41. https://doi.org/10.1162/EDFP

Castleman, B. L., \& Page, L. C. (2014). A trickle or a torrent? Understanding the extent of summer "melt" among college-intending high school graduates. Social Science Quarterly, 95(1), 202-220. https://doi.org/10.1111/ssqu.12032

Castleman, B. L., \& Page, L. C. (2015). Summer nudging: Can personalized text messages and peer mentor outreach increase college going among low-income high school graduates? Journal of Economic Behavior and Organization, 115, 144-160.

Castleman, B. L., \& Page, L. C. (2016). Freshman year financial aid nudges: An experiment to increase FAFSA renewal and college persistence. Journal of Human Resources, 29, 1-31. https://doi.org/10.3368/jhr.51.2.0614-6458R

Clinedinst, M., \& Koranteng, A.-M. (2017). State of College Admission.

Cochrane, D., LaManque, A., \& Szabo-Kubitz, L. (2010). After the FAFSA: How Red Tape can Prevent Eligible Students from Receiving Financial Aid.

Cunha, J. M., Miller, T., \& Weisburst, E. (2018). Information and College Decisions: Evidence From the Texas GO Center Project. Educational Evaluation and Policy Analysis, 40(1), 151-170. https://doi.org/10.3102/0162373717739349

Dika, S. L., \& Singh, K. (2002). Applications of Social Capital in Educational Literature: A 
Critical Synthesis. Review of Educational Research, 72(1), 31-60.

Dynarski, S., Libassi, C. J., Michelmore, K., \& Owen, S. (2018). Closing the Gap: The Effect of a Targeted, Tuition-Free Promise on College Choices of High-Achieving, Low-Income Students.

Ehrlich, S. (2013). 2013 Guide to Text Messaging Regulations \& Best Practices.

Evans, B. J., Nguyen, T. D., Tener, B. B., \& Thomas, C. L. (2017). Federal Pell Grant Eligibility and Receipt: Explaining Nonreceipt and Changes to EFC Using National and Institutional Data Recommended Citation. Journal of Student Financial Aid, 47(3), 45-84.

Gurantz, O., Howell, J., Hurwitz, M., Larson, C., Pender, M., \& White, B. (2019). Realizing Your College Potential? Impacts of College Board's RYCP Campaign on Postsecondary Enrollment (No. 19-40; EdWorkingPaper).

Hoxby, C., \& Avery, C. (2012). The Missing “One-Offs”: The Hidden Supply of HighAchieving, Low Income Students (NBER Working Paper Series).

Hoxby, C., \& Turner, S. (2013). Expanding college opportunities for high-achieving, low income students (No. 12-014; Stanford Institute for Economic Policy Research Discussion Paper Series).

Hurwitz, M., \& Howell, J. (2013). Measuring the Impact of High School Counselors on College Enrollment: College Board Advocacy \& Policy Center Research Brief (Issue February).

Hyman, J. (2019). Can Light-Touch College-Going Interventions Make a Difference? Evidence from a Statewide Experiment in Michigan. O(0), 1-32. https://doi.org/10.1002/pam.22155

Klasik, D. (2012). The College Application Gauntlet: A Systematic Analysis of the Steps to Four-Year College Enrollment. Research in Higher Education, 53(5), 506-549.

Marx, B. M., \& Turner, L. J. (2018). Student Loan Nudges: Experimental Evidence on Borrowing and Educational Attainment (Issue January). https://doi.org/10.3386/w24060

Mullainathan, S., \& Spiess, J. (2017). Machine Learning: An Applied Econometric Approach. Journal of Economic Perspectives, 31(2), 87-106.

Nurshatayeva, A., Page, L. C., White, C. C., \& Gehlbach, H. (2020). Proactive student support using artificially intelligent conversational chatbots: The importance of targeting the technology Proactive student support using artificially intelligent conversational chatbots: The importance of targeting the technology Proac. 20.

Page, L. C., Castleman, B. L., \& Meyer, K. (2020). Customized Nudging to Improve FAFSA Completion and Income Verification. Educational Evaluation and Policy Analysis, 42(1), 3-21. https://doi.org/10.3102/0162373719876916

Page, L. C., \& Gehlbach, H. (2017). How an Artificially Intelligent Virtual Assistant Helps Students Navigate the Road to College. AERA Open, 3(4), 233285841774922. https://doi.org/10.1177/2332858417749220

Perna, L. W. (2006). Studying College Access and Choice: A Proposed Conceptual Model. In Higher Education: Handbook of Theory and Research (Vol. 21, pp. 99-157). https://doi.org/10.1007/1-4020-4512-3

Perna, L. W., Rowan-Kenyon, H. T., Thomas, S. L., Bell, A., Anderson, R., \& Li, C. (2008). The Role of College Counseling in Shaping College Opportunity: Variations across High Schools. The Review of Higher Education, 31(2), 131-159.

Phillips, M., \& Reber, S. J. (2019a). Does Virtual Advising Increase College Enrollment? In NBER Working Paper Series. https://doi.org/10.1017/CBO9781107415324.004

Phillips, M., \& Reber, S. J. (2019b). Report on the Implementation and Impacts of the $V$ SOURCE College Access Program. https://www.sarahreber.com/vsource 
Roderick, M., Nagaoka, J., Coca, V., \& Moeller, E. (2008). From High School to the Future: Potholes on the Road to College. In Consortium on Chicago School Research (Issue March). https://doi.org/10.3102/0013189X14523039

Salinas, C., \& Lozano, A. (2019). Mapping and recontextualizing the evolution of the term Latinx: An environmental scanning in higher education. Journal of Latinos and Education, 18(4), 302-315. https://doi.org/10.1080/15348431.2017.1390464

Thaler, R. H., \& Sunstein, C. R. (2008). Nudge: Improving Decisions about Health, Wealth, and Happiness. Yale University Press.

Weixler, L., Valant, J., Bassok, D., Doromal, J., \& Gerry, A. (2019). Helping Parents Navigate the Early Childhood Enrollment Process: Experimental Evidence from New Orleans. 
Table 1: Characteristics of Respondents and Nonrespondents

\begin{tabular}{lcccc}
\hline Characteristic & Respondents & Nonrespondents & Difference & $\mathrm{N}$ \\
\hline Latinx (\%) & 42.7 & 41.6 & -0.8 & 14,483 \\
White (\%) & 27.3 & 27.6 & 1.2 & 14,483 \\
Asian (\%) & 14.4 & 14.6 & -0.8 & 14,483 \\
Black (\%) & 9.5 & 11.0 & 0.4 & 14,483 \\
Mixed Race (\%) & 4.5 & 3.5 & 0.5 & 14,483 \\
Female (\%) & 56.0 & 52.2 & $2.7^{* *}$ & 14,860 \\
First Generation (\%) & 26.6 & 28.6 & -1.1 & 14,860 \\
Low Income (\%) & 57.7 & 60.8 & -0.9 & 14,860 \\
GPA & 3.6 & 3.5 & $0.0^{* *}$ & 14,568 \\
SAT Reading Score & 576.3 & 573.5 & $2.6^{* *}$ & 12,808 \\
SAT Math Score & 569.1 & 570.6 & -0.6 & 12,808 \\
High School in a City (\%) & 36.2 & 38.1 & $-2.3^{* *}$ & 14,860 \\
High School in Suburbs (\%) & 38.8 & 37.5 & 0.9 & 14,860 \\
High School in Town (\%) & 5.5 & 5.2 & $0.9^{*}$ & 14,860 \\
High School in Rural Area (\%) & 12.8 & 11.6 & $1.4^{* *}$ & 14,860 \\
\hline N & 10,570 & 4,290 & 14,860 & 14,860 \\
\hline The first colmn shows & & & & \\
\hline
\end{tabular}

The first column shows the characteristics of students who responded to at least one counselor broadcast, and the second column shows the characteristics of students who never responded to any counselor broadcast.

${ }^{*} p<0.05,{ }^{* *} p<0.01$ 
Table 2: Counselor Broadcasts

\begin{tabular}{|c|c|c|c|}
\hline$\#$ & Topic & Date Range & Broadcast Language \\
\hline 1 & College List & $\begin{array}{l}\text { October - } \\
\text { December }\end{array}$ & Do you know where you want to apply to college? \\
\hline 2 & $\begin{array}{l}\text { FAFSA } \\
\text { (Application) }\end{array}$ & $\begin{array}{l}\text { December - } \\
\text { January }\end{array}$ & Have you had a chance to submit your FAFSA app yet? \\
\hline 3 & $\begin{array}{l}\text { FAFSA } \\
\text { (Verification) }\end{array}$ & $\begin{array}{l}\text { January } \quad- \\
\text { February }\end{array}$ & $\begin{array}{l}\text { 1. Do you need to complete verification steps for your } \\
\text { FAFSA? } \\
\text { 2. Have you had a chance to submit your } \\
\text { FAFSA/TASFA/DREAM ACT app yet? }\end{array}$ \\
\hline 4 & $\begin{array}{l}\text { FAFSA (Student } \\
\text { Aid Report) }\end{array}$ & $\begin{array}{l}\text { February } \\
\text { March }\end{array}$ & $\begin{array}{l}\text { 1. Have you checked your Student Aid Report (SAR) in your } \\
\text { FAFSA to make sure all of your colleges are listed? } \\
\text { 2. Submit your FAFSA/Dream Act/TASFA asap to meet } \\
\text { deadlines! Do you know how? }\end{array}$ \\
\hline 5 & $\begin{array}{l}\text { Financial Aid } \\
\text { Offer }\end{array}$ & March - April & $\begin{array}{l}\text { If you applied for aid, you will receive a Financial Aid Award } \\
\text { Offer from the colleges that accept you. Did you get these? }\end{array}$ \\
\hline 6 & College Decision & April - May & Have you decided on which college you're going to attend? \\
\hline 7 & Summer Steps & May - June & $\begin{array}{l}\text { If you're starting college in the fall, there are important steps } \\
\text { to take over the summer. Do you know what you need to do? }\end{array}$ \\
\hline 8 & Finding Bill & June - August & $\begin{array}{l}\text { You'll most likely need to pay your fall college bill in } \\
\text { July/Aug. Have you seen your bill yet? }\end{array}$ \\
\hline 9 & Paying Bill & $\begin{array}{l}\text { August - } \\
\text { September }\end{array}$ & Have you already paid your fall college bill? \\
\hline 10 & Other Questions & $\begin{array}{l}\text { August - } \\
\text { October }\end{array}$ & Do you have any other questions? \\
\hline
\end{tabular}

Counselor broadcasts are the initial text messages that counselors text to students and are intended to begin a conversation about a particular topic in the college application process.

The third and fourth broadcasts varied based on students' response to the second broadcast: students received the verification and SAR broadcasts only if they told counselors that they had already submitted FAFSA; if not, they received broadcasts reminding them to submit FAFSA/TASFA/Dream Act applications. 
Table 3: Accuracy in Predictive Performance of Machine Learning Methods

\begin{tabular}{lccccccc}
\hline \hline $\begin{array}{l}\text { Type of } \\
\text { Productive Engagement }\end{array}$ & SVM & $\begin{array}{c}\text { Neural } \\
\text { Net }\end{array}$ & $\begin{array}{c}\text { Elastic } \\
\text { Net }\end{array}$ & Ridge & LASSO & $\begin{array}{c}\text { Random } \\
\text { Forest }\end{array}$ & Ensemble \\
\hline College List & 96.7 & 90.2 & 86.2 & 81.9 & 84.7 & 93.4 & 86.3 \\
College Applications & 98.9 & 86.9 & 68.4 & 90.1 & 78.7 & 91.1 & 90.1 \\
FAFSA & 94.1 & 87.7 & 81.7 & 82.4 & 79.8 & 95.0 & 93.6 \\
Financial Aid Offer & 96.1 & 89.7 & 87.3 & 86.2 & 84.8 & 95.9 & 91.8 \\
Summer Steps & 96.9 & 9.3 & 87.6 & 72.5 & 87.6 & 94.3 & 87.6 \\
Any Productive Engagement & 97.8 & 84.1 & 72.7 & 70.6 & 71.3 & 88.5 & 90.6 \\
\hline
\end{tabular}

This table shows the percent of interactions in the test set that each machine learning method correctly predicted. 


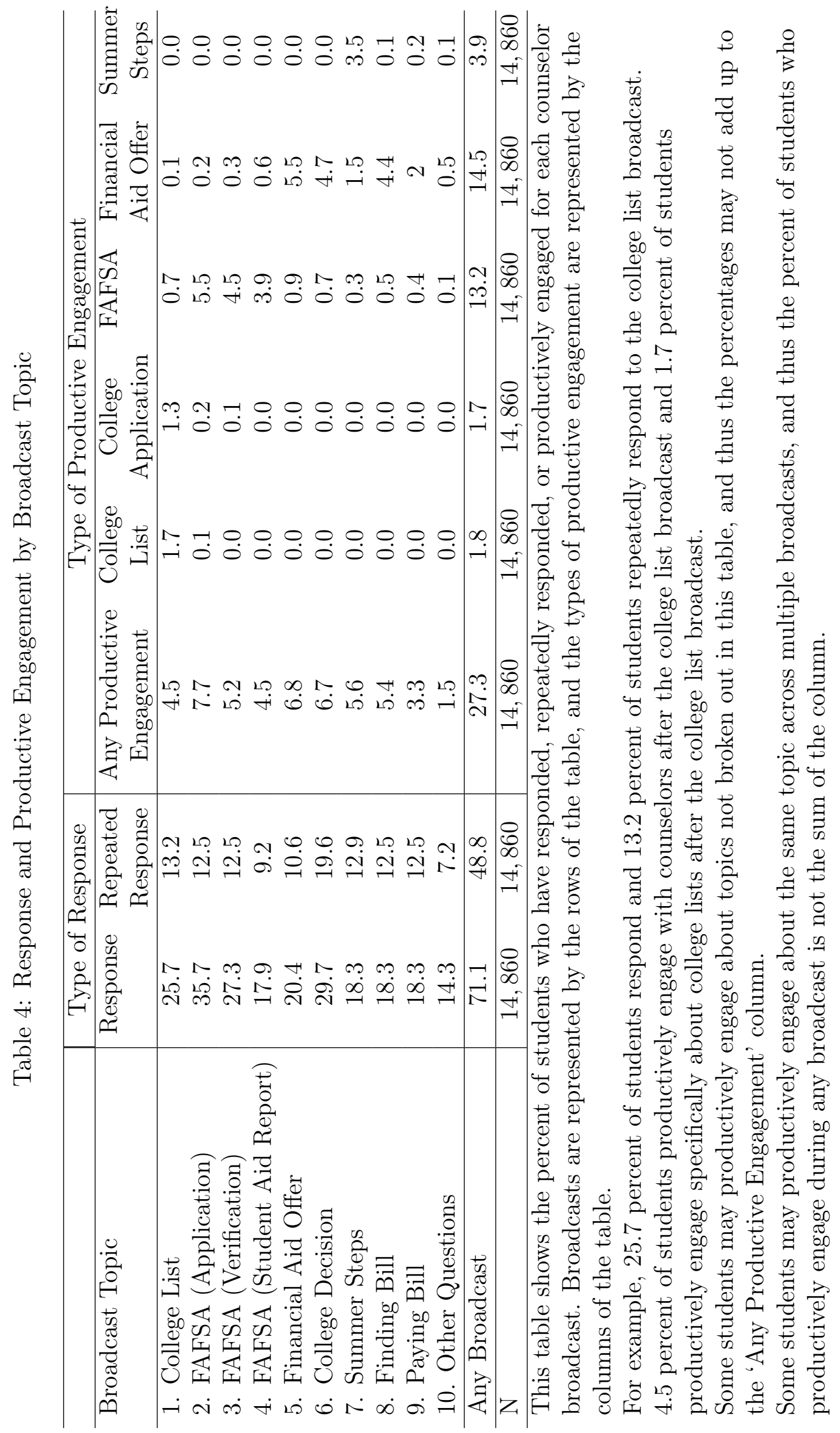




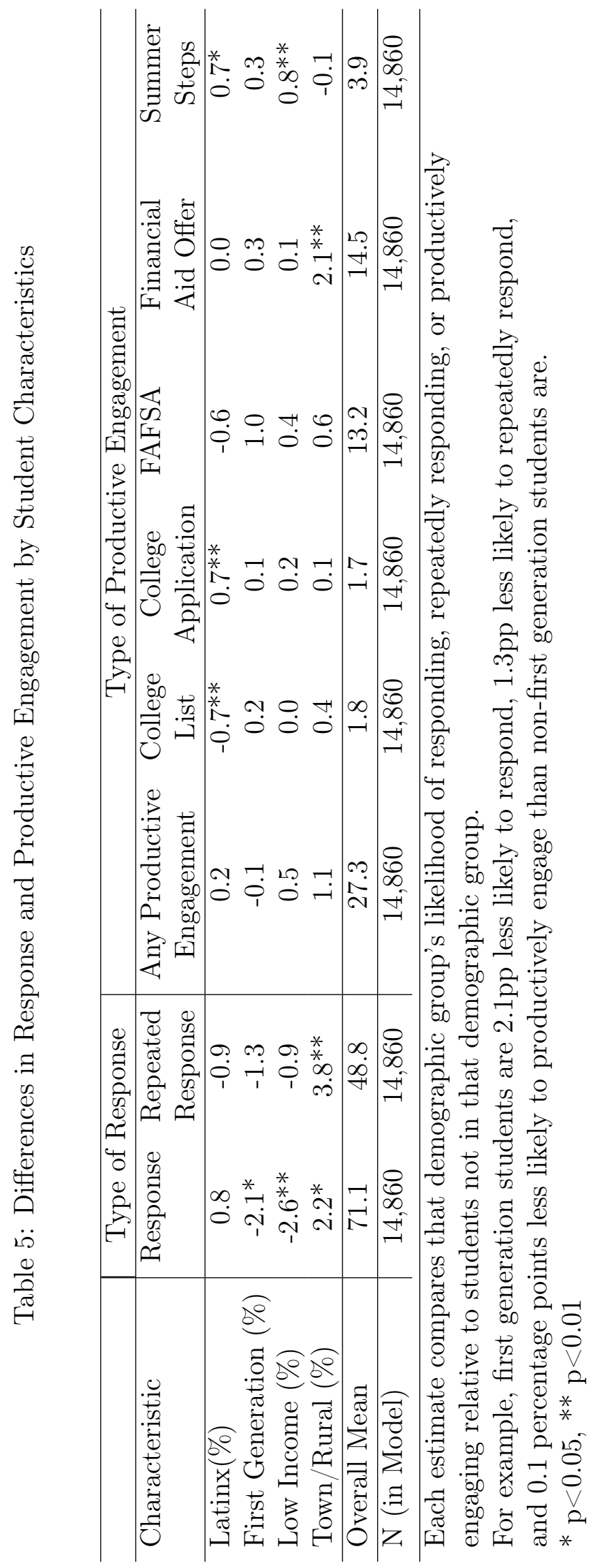


Figure 1: Productive Engagement by Month

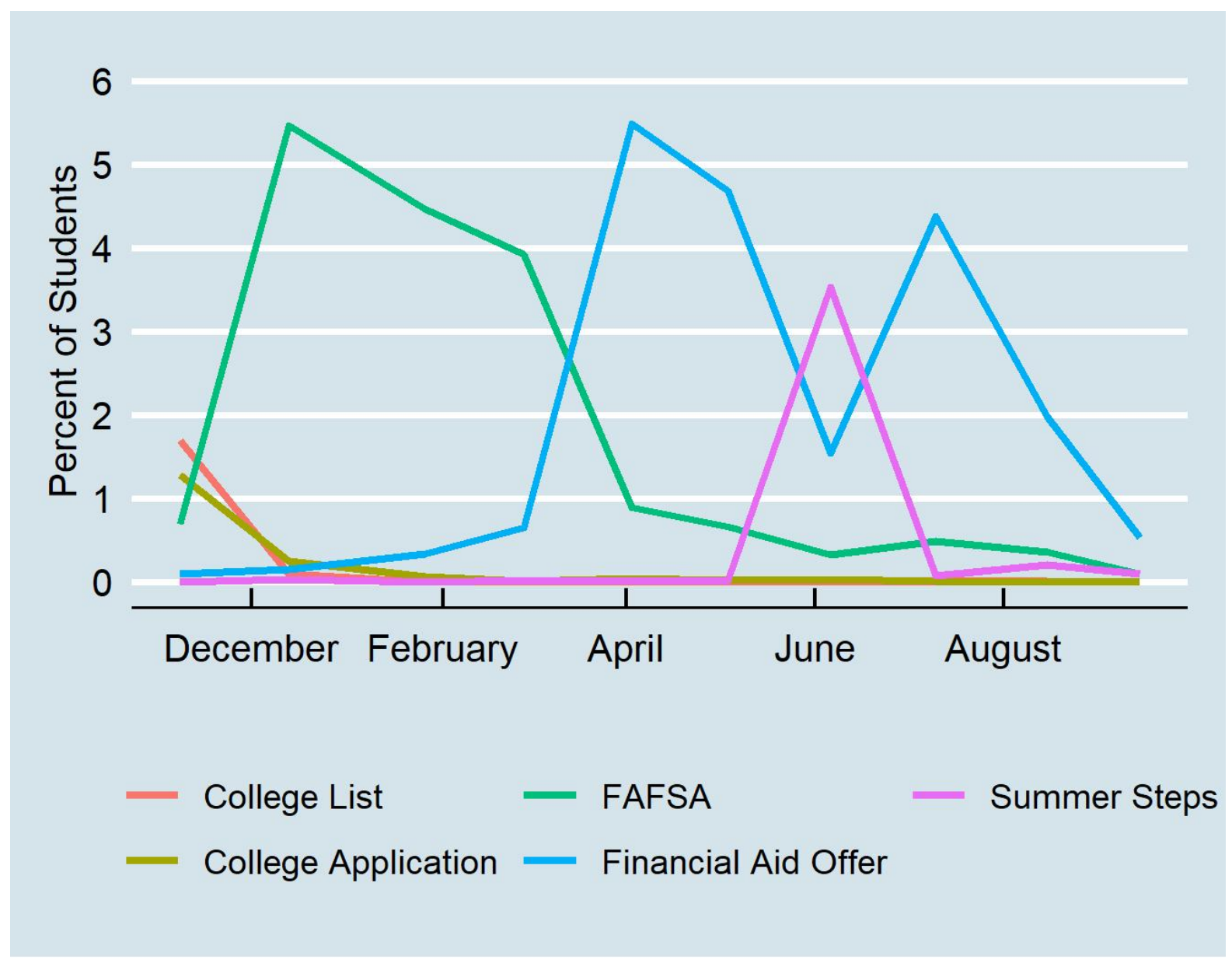




\section{Appendix A: Productive Engagement Codebook}

\begin{tabular}{|c|c|}
\hline Productive Engagement & Not Productive Engagement \\
\hline $\begin{array}{l}\text { The student asks a question, expresses } \\
\text { confusion, complains, or brings up a } \\
\text { new topic related to the application } \\
\text { process, to which the counselor } \\
\text { responds with information or a } \\
\text { suggestion. This information can be } \\
\text { given as a question. } \\
\text { The student states something that is } \\
\text { incorrect, and the counselor corrects } \\
\text { them. }\end{array}$ & $\begin{array}{l}\text { The student asks a question, and the } \\
\text { counselor responds with a follow up } \\
\text { question that the student doesn't } \\
\text { respond to. The follow up question } \\
\text { does not include any helpful } \\
\text { information. } \\
\text { The counselor asks students a series } \\
\text { of questions, and then determines } \\
\text { that the student is on the right } \\
\text { track/doing the right thing. The } \\
\text { student never expresses confusion or } \\
\text { asks a question about the process. }\end{array}$ \\
\hline $\begin{array}{l}\text { - The counselor asks the student to take a } \\
\text { step that they have not yet taken. } \\
\text { The student realizes that they had not } \\
\text { completed a step that they thought they } \\
\text { had. }\end{array}$ & $\begin{array}{l}\text { The counselor asks students to } \\
\text { confirm that they have taken a step, } \\
\text { and the student confirms that they } \\
\text { have. }\end{array}$ \\
\hline $\begin{array}{l}\text { The counselor provides students with } \\
\text { information that the student did not } \\
\text { request (or express confusion about), } \\
\text { and the student indicates that this is new } \\
\text { information. }\end{array}$ & $\begin{array}{l}\text { - The counselor provides students with } \\
\text { information that the student did not } \\
\text { request (or express confusion about), } \\
\text { and the student does not } \\
\text { acknowledge that this is new } \\
\text { information (this includes } \\
\text { nonresponse). }\end{array}$ \\
\hline $\begin{array}{l}\text { The student sends in a screenshot of } \\
\text { something and the counselor helps them } \\
\text { analyze it. }\end{array}$ & $\begin{array}{l}\text { - The student tries to send in a } \\
\text { screenshot of something, it doesn't } \\
\text { go through, and the student stops } \\
\text { responding. }\end{array}$ \\
\hline
\end{tabular}

Note: The interaction is coded as containing productive engagement if there are one or more instances of productive engagement. 


\section{Summary of Codes}

\begin{tabular}{|l|l|}
\hline Code Name & Code Description \\
\hline College List & $\begin{array}{l}\text { Choosing colleges, assessing fit with colleges, and learning more about } \\
\text { particular schools or majors. }\end{array}$ \\
\hline $\begin{array}{l}\text { College } \\
\text { Application }\end{array}$ & $\begin{array}{l}\text { Application deadlines, application fee waivers, how to submit SAT/ACT } \\
\text { scores, and how to write college essay, etc. }\end{array}$ \\
\hline $\begin{array}{l}\text { Financial Aid } \\
\text { Application }\end{array}$ & $\begin{array}{l}\text { Finding and submitting FAFSA, TASFA, Cal Grant, and any scholarships; } \\
\text { checking the Student Aid Report (SAR); and submitting additional } \\
\text { information to FAFSA/colleges (financial aid verification). }\end{array}$ \\
\hline $\begin{array}{l}\text { Financial Aid } \\
\text { Offer }\end{array}$ & $\begin{array}{l}\text { Finding financial aid offer (through online portal, calling financial aid office, } \\
\text { or finding letter in the mail); explaining the offer; discussing loans, work } \\
\text { study, working over the summer, and creating a payment plan with students' } \\
\text { family; finding bill, bill deadline, and what bill contains. }\end{array}$ \\
\hline $\begin{array}{l}\text { College } \\
\text { Decision }\end{array}$ & $\begin{array}{l}\text { Deciding between multiple schools and discussing schools that the student } \\
\text { has already applied to/been accepted to. }\end{array}$ \\
\hline Summer Steps & Placement tests, immunization forms, signing up for orientation, etc. \\
\hline
\end{tabular}




\section{Productive Engagement Categories}

\section{College List}

- Applying to additional schools

- Learning about the schools that the student is interested in

- Attending college while joining the military

- Chances of being admitted to a school, and academic fit (comparing SAT scores, GPA, etc.)

- Choosing a major, or thinking about future career options

- What schools pay attention to when making college decisions

\section{College Application}

- Application deadlines

- Sending information to colleges: SAT/ACT scores, transcripts, essays, the Common app, letters of recommendation

- Application fee waivers

- Whether student needs to do anything additional once they've been deferred

- Finding application website

\section{Financial Aid Application}

Applying

- FAFSA/Cal Grant/TASFA/CSS Profile

- Financial aid deadlines

- Contacting schools' financial aid offices to explain students' specific financial circumstances before being admitted

- $\quad$ Student aid report (SAR)

- Finding and submitting scholarships

Verification and Fixing Incomplete or Incorrect Financial Aid Offers

- FAFSA requesting verification steps

- Colleges requesting additional financial information after a student is accepted, which will affect a student's financial aid award letter

- Not having all grants/scholarships listed on financial aid award letter

- Ensuring that state grants are applied to the school students want to attend

\section{Financial Aid Offer}

\section{Finding Financial Aid Offer}

- Student navigates to online portal to check if financial aid is there (whether it's there or not).

- Call school's financial aid office to inquire about where the financial aid award offer is

- Student asks where to find additional information about their award for the following year

Understanding Financial Aid Offer

- Explaining a students' individual financial aid award amounts

- Understanding differences between grants and loans

- Understanding loan interest rates 
- Defining terms (Parent PLUS, work study, subsidized loans, unsubsidized loans, etc.). This can be discussed in direct connection with an award letter, or more general questions.

- Understanding the loans that have been offered to students

- Accepting financial aid/loans (and deadlines for this)

- General questions about how financial aid works after the student has been admitted

Affording College

- Strategizing how to pay for college/creating a plan to pay

- Work study

- Taking out loans

- Steps to take out loans (entrance loan counseling and the master promissory note, MPN)

- Whether taking out loans is a good idea

- How loans might affect credit scores

- Talking to parents about paying for college

- Working over the summer to pay for college

- Payment plans

- Talking through how to pay for rent

Bill

- Bill deadline

- What bill consists of/what a bill is

- Logging into portal to view bill

- Submitting/paying bill

- Requesting an extension for paying the bill

\section{College Decision}

- Pros and cons of going to different schools

- Discussions about a school that a student has already applied to, but hasn't yet accepted the offer

- Deciding whether to attend college at all

- Deciding whether to take a gap year

- Creating a plan to go to college in the future (not attending this year)

\section{Summer Steps}

- How to sign up for orientation or what orientation is

- How to sign up for placement tests or what they entail

- How to fill out immunization forms

- How to create a school account (after the student was admitted) - unless the student is creating an account to view their financial aid award letter

- Discussions about the school the student has decided to attend

- Sending information to colleges after being admitted (like transcripts and AP scores)

- Signing up for classes, and finding cheap books

- Student asking questions about the school that they are going to attend 


\section{Appendix B: Methods Supplement}

\section{Inter-Rater Reliability}

Two researchers code a random subset of the interactions to measure inter-rater reliability. Appendix Table B1 shows Cohen's kappa for each of the six codes, and tests whether kappa is significantly above the threshold of 0.65 using a simulated data method. This method generates many datasets with a kappa below 0.65 , then determines whether less than five percent

of the samples have a kappa greater than the observed kappa (Shaffer, 2017). All the codes have a kappa above 0.83 and are statistically significantly above the threshold of 0.65 . For interactions in which the coders differed, the coders discussed their rationales for their chosen codes and came to a common agreement about which codes were more appropriate for that interaction.

\section{Random Sampling Process}

Because the incidence of the codes of interest varied by type of productive engagement, the original random sample led us to find many instances of productive engagement about financial aid applications and financial aid offers but not as many instances for college lists, college applications and summer steps. The machine learning algorithms need a sufficient number of positive instances of each code for training purposes. I subsequently randomly oversampled broadcasts 1 (for college lists and college applications) and broadcast 7 (for summer steps) to increase the number of positive instances for college lists, college applications, and summer steps. After the oversampling, the two coders found 50 instances of productive engagement about college lists, 47 instances of college applications, 130 instances of financial aid applications, 113 instances of financial aid offers, 51 instances of summer steps, and 333 instances of any productive engagement. I found that these numbers of positive instances were 
sufficient to achieve high levels of accuracy in training the machine learning algorithms. I

originally also included a college decision productive engagement code but eventually dropped it due to the infrequency with which it occurred in our data. (Even with oversampling productive engagement about college decisions only occurred 9 times in the training data, which meant both that it would be difficult to train a machine learning algorithm on this code, and that the overall percent of productive engagement about college decisions would be very close to zero.) Note that the raw counts of how frequently productive engagement occurs in the training data do not allow for a direct calculation of the incidence of these codes in the overall sample because 1) they do not include nonrespondents (and the rate of nonresponse varies by broadcast), 2) some codes have been oversampled (and thus college lists are overrepresented, for example). I ended up with a total of 551 hand-coded interactions.

\section{Machine learning}

I apply seven different machine learning methods in my sample to assess which method achieves the highest prediction performance: LASSO, ridge, elastic net, random forests, neural net, and support vector machine.

LASSO, ridge, and elastic net are all types of regularized regression, which are the most popular forms of regression with a high-dimensional dataset (Gentzkow et al., 2017). As opposed to Ordinary Least Squares (OLS) estimators, which minimizes in-sample error and leads to an unbiased estimate, these methods allow for more bias to optimize for out-of-sample performance (Mullainathan \& Spiess, 2017). To do so, regularized regression affixes a penalty to large coefficients that would create additional variance in predictions. LASSO's penalty assigns some coefficients to zero while shrinking other coefficients towards zero, ridge's penalty smoothly shrinks coefficients towards zero, and elastic net combines the penalties of LASSO and ridge. I 
apply these three methods by using cv.glmnet in R, which allows me to tune each algorithm to optimize for out-of-sample performance. More specifically, I use ten-fold cross-validation to find the shrinkage parameter (lambda) that controls the amount of regularization for each of the three methods. This means that I iteratively estimate LASSO, ridge, and elastic net models on a rotating 90 percent of the data and estimate how well each of the methods predicts the remaining 10 percent of the observations using a range of different lambdas. I use the lambdas for each of the three methods that optimize out-of-sample performance.

Random forests aggregate multiple classification trees, which continuously split the data into two parts based on the variable and split value that achieves the best predictive fit until a stopping rule is reached. When the stopping rule is reached, the average value for the observations in each end node (or "leaf") serves as the prediction for observations with similar characteristics (according to that tree's splitting variables and values) that were not used in the training of the tree. Random forests fit many trees to out-of-bag (OOB) samples, in which the prediction for each observation is only generated by trees trained on data that excluded that observation. The final classification for each observation is determined by the most common classification for that observation across trees (Hastie et al., 2009). The OOB sampling process is very similar to $\mathrm{n}$-fold cross validation, which means that these methods require little tuning and can perform well out-of-the-box with standard software like RandomForest in R, which I use here (Hastie et al., 2009; Liaw \& Wiener, 2002).

Neural networks model the outcome as a nonlinear function based on linear combinations of the predictors. Model performance is optimized through a process known as back-propagation, a form of gradient descent (Hastie et al., 2009). To do this, I use neuralnet in R, which 
implements a feedforward neural network with resilient backpropagation (Riedmiller \& Braun, 1993; Schmidhuber, 2015).

Support Vector Machine (SVM) is one of the most widely used (and often best performing) classifier in social science applications (Hopkins \& King, 2010). In a two-variable context, SVM finds the line that best separates the two classes (in this instance, productive engagement versus non-productive engagement). In a many variable context, SVM instead finds a hyperplane that creates the biggest margin between the two classes (Hastie et al., 2009). I implement this using the e1071 package in $\mathrm{R}$ and use a radial kernel, which performs well outof-sample.

I also estimate an ensemble, which has been found to often perform better than any individual method (Athey et al., 2019). To do this, I generate a prediction for each observation in my training set using ten-fold cross validation, then estimate a constrained regression of the labels on the six predicted codes from the six methods (constraining the coefficients to be positive and sum to one). This generates ensemble weights that determine what weight each method gets in the ensemble.

Neural nets, elastic net, ridge, LASSO, and the ensemble all produce values between 0 and 1 . To convert these probabilities into the final classification, I find the threshold value that optimizes for predictive performance for each algorithm by maximizing sensitivity and specificity. For example, if the optimal threshold value found through cross-validation for a given method is 0.6 , then all predicted probabilities greater than 0.6 that the algorithm produced are converted to $1 \mathrm{~s}$ (productive engagement), and all probabilities lower than 0.6 are converted to Os (not productive engagement). 


\section{Assessing predictive performance}

To assess model performance, I apply each of the methods to my training data $(75 \%$ of my data) and assess how well each does at predicting the codes for my test data $(25 \%$ of my data). For models that perform well in predicting productive engagement in the test set, this indicates that they do well at predicting observations out-of-sample (i.e. interactions that I have not hand-coded).

I use three metrics to assess model performance: accuracy, sensitivity, and specificity. Accuracy is the proportion of interactions that the model correctly coded, sensitivity is the proportion of true productive engagement that is correctly coded by the algorithm as productive engagement (true positive rate), and specificity is the proportion of true non-productive engagement that is correctly coded by the algorithm as non-productive engagement (true negative rate).

I find that SVM performs very well across all the productive engagement codes. It correctly categorizes 94 to 99 percent of each of the codes overall (accuracy) (see Table 3), 95 to 100 percent of the true negatives (specificity) for each of the codes (see Appendix Table B2, panel a), and 64 to 100 percent of the true positives (sensitivity) for each of the codes (see Appendix Table B2, panel b). Although this performance is very strong overall, the next section discusses how the lower sensitivity for some of the codes (like college list and summer steps) may affect the overall proportions.

\section{Adjusting Proportions for Predictive Performance}

Although SVM's predictions are highly accurate for each individual interaction, Hopkins and King (2010) have shown that the sample-level proportions of interactions that contain 
productive engagement may be biased if the algorithm consistently misclassifies true positives more or less frequently than true negatives (based on the sensitivity and specificity). However, I can generate approximately unbiased and statistically consistent proportions by adjusting the proportions based on the performance in the test sample (Hopkins \& King, 2010). The proportion of interactions that are predicted to contain productive engagement (for each of the six codes) $(\widehat{D}=1)$ must be either true positives or false positives:

$$
P(\widehat{D}=1)=P(\widehat{D}=1 \mid D=1)] P(D=1)+(1-P(\widehat{D}=0 \mid D=0)) P(D=0),
$$

where $\widehat{D}$ represents the binary prediction for each of the six codes and $D$ represents the true binary value for each of the six codes. $P(\widehat{D}=1 \mid D=1)$ represents the sensitivity of the model, and $P(\widehat{D}=0 \mid D=0)$ represents the specificity of the model (see Appendix Table B2 for the sensitivities and specificities for SVM for each of the six codes). I adjust the reported specificities to account for nonresponse, by counting all nonresponses as being correctly coded 100 percent of the time for not containing productive engagement. To estimate the true proportions, I rearrange this equation to produce the approximately unbiased proportions for each of the six codes:

$$
P(D=1)=\frac{P(\widehat{D}=1)-(1-\text { specificity })}{\text { sensitivity }-(1-\text { specificity })}
$$

I apply this adjustment to the proportions in my sample and show the adjusted proportions in Appendix Table B3. In general, the adjusted proportions remain similar to the unadjusted proportions. However, the proportion of students who productively engage about college lists increases from 1.7 to 2.7 percent in the first broadcast, the proportion of students who productively engage about financial aid offers increases somewhat (e.g. from 5.5 to 6.0 after the fifth broadcast), and the proportion of students who productively engage about summer steps increases from 3.5 to 5.3 after the seventh broadcast. The proportion of students who 
productively engage about any topic also decreases somewhat (e.g. from 7.7 to 7.1 after the second broadcast). Although these adjustments do change some of the proportions, they do not change the proportions in relative terms (i.e. students still discuss financial aid offers the most, followed by FAFSA, summer steps, and college lists).

Because this adjustment procedure only produces adjusted overall proportions, and does not adjust individual predictions, my primary analyses still show the unadjusted predictions. This allows for an analysis of the percent of students who productively engage on each topic (as opposed to the percent of interactions), shown as the second to last row of Table 4, as well as for associations between productive engagement and student characteristics (Table 5). 


\section{References for Appendix B}

Athey, S., Bayati, M., Imbens, G., \& Qu, Z. (2019). Ensemble Methods for Causal Effects in Panel Data Settings Ensemble Methods for Causal Effects in Panel Data Settings. American Economic Review Papers and Proceedings, 1-13. http://www.nber.org/papers/w25675

Gentzkow, M., Kelly, B. T., \& Taddy, M. (2017). Text as Data (No. 23276; NBER Working Paper Series).

Hastie, T., Tibshirani, R., \& Friedman, J. (2009). The Elements of Statistical Learning (2nd ed.). Springer.

Hopkins, D. J., \& King, G. (2010). A method of automated nonparametric content analysis for social science. American Journal of Political Science, 54(1), 229-247.

Liaw, A., \& Wiener, M. (2002). Classification and Regression by randomForest. $R$ News, 2(3), $18-22$.

Mullainathan, S., \& Spiess, J. (2017). Machine Learning: An Applied Econometric Approach. Journal of Economic Perspectives, 31(2), 87-106.

Riedmiller, M., \& Braun, H. (1993). Direct adaptive method for faster backpropagation learning: The RPROP algorithm. 1993 IEEE International Conference on Neural Networks, 586-591. https://doi.org/10.1109/icnn.1993.298623

Schmidhuber, J. (2015). Deep Learning in neural networks: An overview. Neural Networks, 61, 85-117. https://doi.org/10.1016/j.neunet.2014.09.003

Shaffer, D. W. (2017). Quantitative Ethnography. Cathcart Press. 
Table B1: Inter-Rater Reliability of Productive Engagement Codes

\begin{tabular}{lc}
\hline \hline Type of Productive Engagement & Kappa \\
\hline College List & $0.91 * *$ \\
College Applications & $0.88 * *$ \\
FAFSA & $0.86 * *$ \\
Financial Aid Offer & $0.83 * *$ \\
Summer Steps & $0.96 * *$ \\
Any Productive Engagement & $0.91 * *$ \\
\hline
\end{tabular}

This table shows the inter-rater reliability for each of the productive engagement codes. Asterisks indicate whether kappa $>0.65$. $\mathrm{p}<0.05^{*}, \mathrm{p}<0.01 * *$ $\mathrm{N}=244$ 
Table B2: Predictive Performance of Machine Learning Methods

(a) Specificity

\begin{tabular}{lccccccc}
\hline \hline $\begin{array}{c}\text { Type of } \\
\text { Productive Engagement }\end{array}$ & SVM & $\begin{array}{c}\text { Neural } \\
\text { Net }\end{array}$ & $\begin{array}{c}\text { Elastic } \\
\text { Net }\end{array}$ & Ridge & LASSO & $\begin{array}{c}\text { Random } \\
\text { Forest }\end{array}$ & Ensemble \\
\hline College List & 100 & 92.9 & 85.7 & 81.0 & 84.1 & 100 & 84.9 \\
College Applications & 100 & 93.8 & 66.7 & 91.5 & 79.1 & 98.4 & 91.5 \\
FAFSA & 94.6 & 91.0 & 78.4 & 82.9 & 74.8 & 98.2 & 92.8 \\
Financial Aid Offer & 98.0 & 95.1 & 86.3 & 83.3 & 82.4 & 100 & 91.2 \\
Summer Steps & 100 & 0.0 & 87.7 & 69.7 & 87.7 & 99.2 & 87.7 \\
Any Productive Engagement & 94.5 & 70.9 & 100 & 92.7 & 94.5 & 70.9 & 81.8 \\
\hline
\end{tabular}

This table shows the percent of interactions in the test set that did not contain each type of productive engagement (e.g. no productive engagement about college lists) that each machine learning method correctly predicted to not contain that type of productive engagement.

Specificity is also known as the true negative rate.

(b) Sensitivity

\begin{tabular}{lccccccc}
\hline \hline \multicolumn{1}{c}{\begin{tabular}{c} 
Type of \\
\multicolumn{1}{c}{ Productive Engagement }
\end{tabular}} & SVM & $\begin{array}{c}\text { Neural } \\
\text { Net }\end{array}$ & $\begin{array}{c}\text { Elastic } \\
\text { Net }\end{array}$ & Ridge & LASSO & $\begin{array}{c}\text { Random } \\
\text { Forest }\end{array}$ & Ensemble \\
\hline College List & 63.6 & 63.6 & 90.9 & 90.9 & 90.9 & 27.3 & 100 \\
College Applications & 87.5 & 12.5 & 87.5 & 75 & 75 & 12.5 & 75 \\
FAFSA & 92.3 & 76.9 & 92.3 & 80.8 & 96.2 & 84.6 & 96.2 \\
Financial Aid Offer & 88.6 & 68.6 & 91.4 & 97.1 & 94.3 & 80 & 94.3 \\
Summer Steps & 66.7 & 100 & 86.7 & 100 & 86.7 & 46.7 & 86.7 \\
Any Productive Engagement & 100 & 92.7 & 54.9 & 56.1 & 56.1 & 100 & 96.3 \\
\hline
\end{tabular}

This table shows the percent of interactions in the test set that contained each type of productive engagement (e.g. productive engagement about college lists) that each machine learning method correctly predicted to contain that type of productive engagement.

Sensitivity is also known as the true positive rate. 

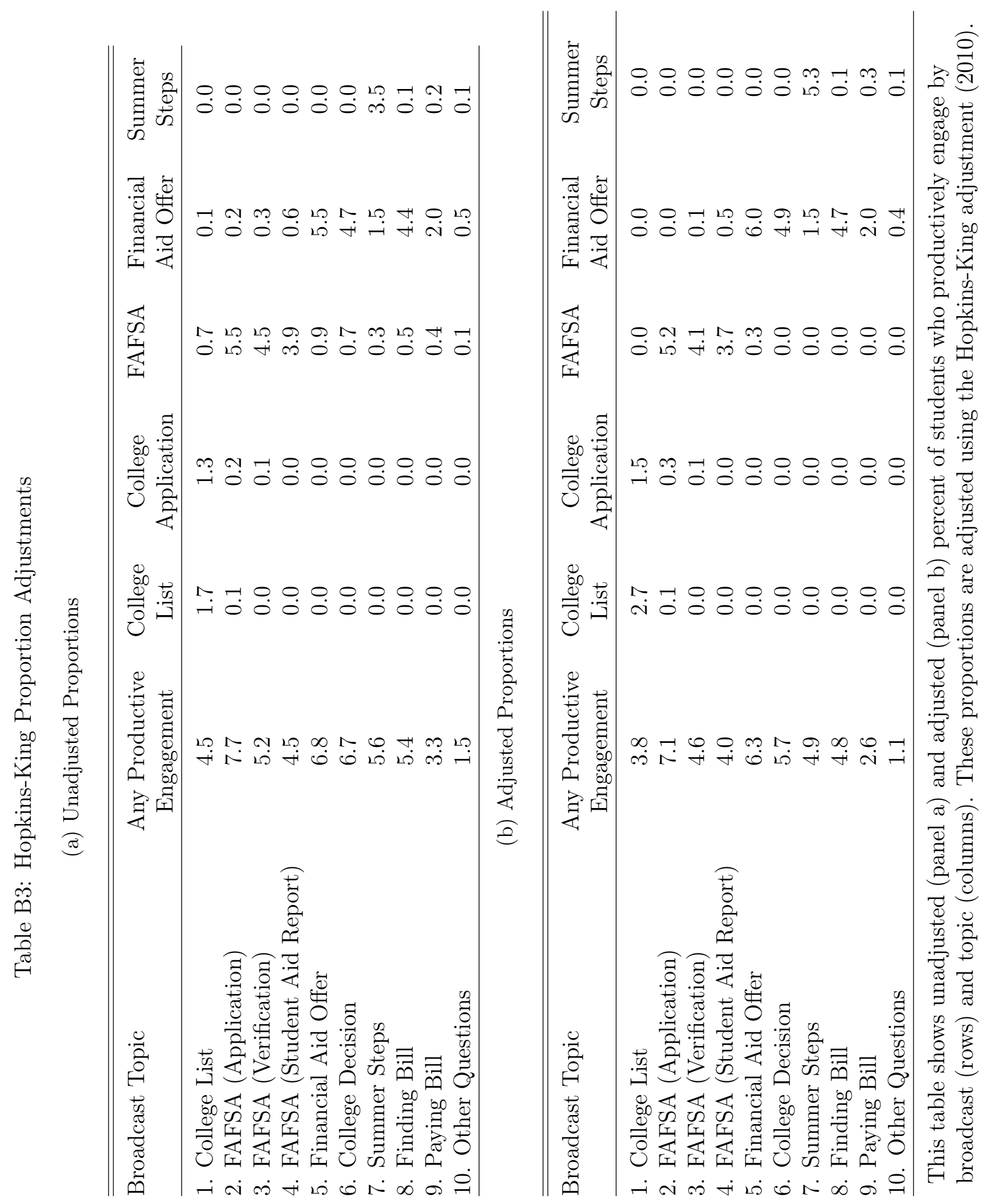